\title{
Service Upon a Non-Resident by Service Upon His Agent
}

TN Henry L. Doherty \& Co. v. Goodman ${ }^{1}$ an appeal from the Supreme

Court of Iowa, ${ }^{2}$ the Supreme Court of the United States held valid, and not contrary to either section 2, Article 4 or the Fourteenth Amendment of the Constitution of the United States, an Iowa statute authorizing service of process upon a citizen of New York by personal service upon his agent, where the action arose out of business transacted in Iowa and the object of the suit was a personal judgment.

The Iowa statute, ${ }^{3}$ in effect since 1851, provided that when an individual has an office or agency "in any county other than that in which the principal resides" for the transaction of business, process may be served upon any agent employed in the office "in all actions growing out of or connected with the business of that office or agency." The Iowa court interpreted the statute to apply to non-residents of Iowa. ${ }^{4}$

The precise question decided in the principal case, though passed upon by state courts, ${ }^{5}$ previously had not been passed upon by the

1 (1935) 55 Sup. Ct. 553.

2 (1934) - Iowa - 255 N. W. 667 . There the service was held vahid. Two judges dissented.

3 Iowa CoDe (1931) \& 11079.

4 Davidson v. Henry L. Doherty \& Co. (1932) 214 Iowa 739, 241 N. W. 700, 91 A. L. R. 1308, noted (1932) 46 HARv. L. Rrv. 153. The statute was also held constitutional, four of the nine judges dissenting. Counsel in the Iowa court in the principal case agreed that the decision in the Davidson case had decided the question but appellant contended it should be overruled. See Daun, The Transaction of Business Within a State by a Non-Resident as a Foundation for Jurisdiction (1934) 19 IowA L. REv. 421.

5 Rauber v. Whitney (1890) 125 Ind. 216, 25 N. E. 186; Guenther v. American Steel Hoop Co. (1903) $116 \mathrm{Ky} .580,76 \mathrm{~S}$. W. 419; Johnson v. Westerfields Adm'r (1911) 143 Ky. 10, 135 S. W. 425; Stoner v. Higginson (1934) - Pa. -, 175 Atl. 527, noted (1935) 83 U. of PA. L. REv. 683. (The court distinguished Flexner v. Farson, infra note 6.)

Contra: Andrews Bros. v. McClanahan (1927) 220 Ky. 504, 295 S. W. 457, (Flexner v. Farson, supra, was considered controlling); Caldwell v. Armour \& Co. (Del. 1899) 1 Penn. 545, 43 Atl. 517. (The statute did not limit the service to actions arising out of business transacted in the state. Plaintiff's alleged cause of action did, however, arise out of business transacted in Delaware); Aikmann v. Sanderson \& Porter (1908) 122 La. 265, 47 So. 600 (The court stressed the fact that the agent served had not been authorized to accept service. This fact eeems unimportant.) ; Cabanne v. Graf (1902) 87 Minn. 510, 92 N. W. 461, 59 L. R. A. 735, $94 \mathrm{Am}$. St. Rep. 722. (The court made much of the fact that defendant had property in the state that might have been attached and relied upon Pennoyer v. Neff (1877) 95 U. S. 714). See Dragon Motor Car Co. Ltd. v. Storrow (1925) 165 Mimn. 95, 205 N. W. 694, holding that the Minnesota Blue Sky Law requiring the appointment of an agent upon whom service might be made did not apply to actions arising out of transactions unconnected with business transacted in that state. 
Supreme Court of the United States, the court of final authority because of the federal constitutional questions involved. Considerable uncertainty existed on the question whether personal service could be made validly upon a non-resident individual because of language in the opinion of Mr. Justice Holmes in Flexner v. Farson ${ }^{6}$ decided in 1919 by the Supreme Court of the United States. In that case the service was made upon an ex-agent of non-residents who had done busmess as partners in Kentucky. It was held insufficient to authorize a personal judgment against the individual principals. ${ }^{7}$ The broad basis for the court's opinion was that doing business in Kentucky did not amount to consent to the service prescribed; that the analogy of suits against a foreign corporation doing business in another state was not sound because, unlike a corporation, the individual cannot be excluded from doing busmess in any state. The decision might have been put upon the narrow ground that the person served was not the nonresident's agent at the time when the summons was served. ${ }^{8}$

A primary principle of Anglo-American law is that no state has the power to send a summons into other states and command a person domiciled there to come into the court of the former state to defend a suit in which plaimtiff seeks a personal judgment or upon failure to appear suffer a judgment by default. ${ }^{9}$ Since the adoption of the Fourteenth Amendment to the Federal Constitution, any judgment so obtained in any state court will be declared void by the Federal Courts. ${ }^{10}$ The defendant, Doherty, then could not have been served effectively

6 (1919) 248 U. S. 289.

7 In Flexner v. Farson, supra note 6, the case came to the Supreme Court of the United States upon writ of error to the Supreme Court of Illinois (268 IIl. 435, 109 N. E. 327 , Ann. Cas. $1916 \mathrm{D}$ 810). A suit was brought in Tlinois on the Kentucky judgment. Only one of the partners, Farson, was served in the suit on the judgment. The Mlinois court held the judgment void. The plaintiff in the case by demurring to defendant's plea admitted that defendant did not reside in Kentucky, was not served there, had not appeared in the action and that W. F. upon whom the summons was served, was not the defendant's agent. "If the Kentucky statute purports to have the effect attributed to it," said Mr. Justice Holmes, "it cannot have that effect in the present case."

Section 51, subdivision 6 of the Kentucky Civil Code provided that in suits against non-resident individuals or partnerships, when the nnembers reside in other states and do business in Kentucky, summons may be served "on the manager, or agent of, or person in charge of, such business in this state."

${ }^{8}$ Scott, Jurisdiction Over Non-Residents Doing Business Within a State (1919) 32 HARv. L. REv. 871, at 891; Hinton, Substituted Service on Non-Residents (1925) 20 Irr. L. REv. 1; Hinton, Process in Actions Against Non-Residents Doing Business Within a State (1934) 32 MrCr. L. Rev. 909.

9 Wilson v. Seligman (1892) 144 U. S. 41 ; Sirdar Gurdyal Singh v. The Rajah of Faridkote [1894] A. C. 670; Scott, Fundamientals of Procedure (1922) p. 36.

10 Pennoyer v. Neff (1877) 95 U.S. 714; Baker v. Baker, Eccles \& Co. (1917) 242 U. S. 394; Beale, The Jurisdiction of Courts Over Foreigners (1913) 26 Harv. L. REv. 283. 
with an Iowa summons while at his domicile, New York, or while anywhere else outside of Iowa. He could, of course, if he had come into Iowa have been served personally with a summons.11 Can he by virtue of the statute be commanded to appear in an Iowa court, when he has done busmess in that state, in a suit arising out of such business when the summons is served upon his agent? Is such service due proces of law? Is it within the competence of the Iowa court? Flexner v. Farson was distinguished. The Supreme Court of the United States, in making affirmative answers to these questions, employed the analogy of service authorized by statutes upon non-resident motorists. No doubt any longer exists that state statutes are valid authorizing personal service upon a non-resident motorist by service outside the state or by service upon a state official designated as his agent. ${ }^{12}$ The judicial opinions and commentators are probably not in accord as to the basis for these holdings. Implied consent to service; the police power of the state; and the right of the state to forbid the doing of specified acts withm its borders unless the non-resident consents to the authority of the courts of that state, and hence the power of the state validly to provide that the doing of certain acts by a non-resident within the state shall subject him to the jurisdiction of the courts as to causes of action arising out of such acts, have been suggested as sound reasons for these decisions. ${ }^{13}$ Recurring to the opinion in the principal case, which was written by Mr. Justice McReynolds, it was said: 'So far as it affects the appellant, the questioned statute goes no further than the principle approved by those opinions (non-resident motorists cases) permits . . . The limitations of section 11079 under different circumstances we do not consider." Previously he had said that Iowa treats the business of sellimg securities as exceptional and subjects it to special

11 Barrell v. Benjamin (1819) 15 Mass. 354.

12 Hess v. Pawloski (1927) 274 U. S. 352 ; Wuchter v. Pizzutti (1928) 276 U. S. 13, 57 A. L. R. 1230; see Note (1928) 16 CALTF. L. REv. 428.

13 Finton, Substituted Service on Non-Residents (1925) 20 IrL. L. REv. 1; Scott, Jurisdiction over Non-Resident Motorists (1926) 39 HARv. L. REv. 563. Professor Scott says: "If a state may, without violating any constitutional limitation, forbid the domg of certain kinds of acts within the state unless and until the person doing the acts has consented to the jurisdiction of the courts of the state as to causes of action arising out of such acts, the state may validly provide that the doing of such acts shall subject him to the jurisdiction of the courts of the state as to such causes of action."

In Hess v. Pawloski (1924) 250 Mass. 22, 144 N. E. 760, 35 A. L. R. 945 , Rugg, C. J., speaks of "police power" and "impled consent." The doctrine of implied consent is based upon a fiction. It is doubted whether the term "police power" means anything more than the power of a state to legislate for the general welfare of the people. Nebbia v. People of the State of New York (1933) 262 N. Y. 259, aff'd (1934) 291 U. S. 502. 
regulation.14 The use of the highways of a state by residents and nonresidents may be and is regulated by many, if not all, the states. ${ }^{15}$ The privilege of selling securities is no doubt subject to proper special regulation. ${ }^{16}$ In view of recent decisions of the Supreme Court of the United States it is perhaps not saying too much to assert that the state has the power to soine extent to regulate any business transacted within its borders. ${ }^{17}$ The opinion in the principal case inakes no express choice of the police power theory; consent theory; or inposition of reasonable conditions theory. Seemingly it impliedly approves the view that a state, constitutionally, may forbid a natural person to do certain acts within its borders and, in the absence of actual consent to the jurisdiction of its courts of actions arising out of such business, may provide that process may be served upon his agent.

The upholding of the Iowa judgment involved the competence or power of the courts of the state of Iowa and also the reasonableness of

14 Laws of Iowa, 1913, c. 137; Laws of Iowa, 1921, c. 189; Laws of Iowa, 1929 , c. 10 . These acts regulate investment companies and the sale of securities in Iowa. The 1929 act (Iowa Securities Act) provides for registration and written consent for service of summons upon the Secretary of State in actions growing out of violations of the provisions of the act. There was no attempt to obtain service under this act in the principal case.

Before the Supreme Court of the United States had upheld the validity of service upon a non-resident motorist, it had held valid a law of New Jersey providing failure of a non-resident motorist, in advance of using the highways, to appoint a state official his agent to receive process, should constitute a misdemeanor. Kane v. New Jersey (1916) 242 U. S. 160.

Mr. Jusice McReynolds in the principal case did not specially discuss the question whether the Iowa statute violated the Privilege and Immunities Clause of the Constitution (Sec. 2, Art. 4). The Iowa Court in Davidson v. Henry I. Doherty \& Co., supra note 4 , at 743 , had pointed out that the Iowa legislation "treats residents of Iowa exactly as it treats residents of all other states. The citizens of each state of the United States are, under this statute, entitled to all the privileges and immunities accorded citizens of this state." This passage was quoted approvingly by $\mathrm{Mr}$. Justice McReynolds.

15 Hendrick v. Maryland (1915) 235 U. S. 610.

16 Hall v. Geiger-Jones Co. (1917) 242 U. S. 539, L. R. A. 1917F 514, Ann. Cas. $1917 \mathrm{C} 643$

17 In Nebbia v. People of the State of New York (1934) 291 U. S. 502, where the Supreme Court of the United States sustained the validity of the New York statute establishing a Milk Control Board, Mr. Justice Roberts said:

"The Fifth Amendment, in the field of federal activity, and the Fourteenth, as respects state action, do not prolibit governmental regulation for the public welfare. They merely condition the exertion of the admitted power, by securing that the end shall be accomplished by methods consistent with due process. And the guaranty of due process, as has often been held, demands only that the law shall not be unreasonable, arbitrary, or capricious, and that the means selected shall have a real and substantial relation to the object sought to be attained. It results that a regulation vahid for one sort of business, or in given circumstances, may be invalid for another sort, or for the same business under other circumstances, because the reasonableness of each regulation depends upon the relevant facts." Ibid. at 525 . 
the method employed to notify the defendant. The method employed seems reasonable. As was pointed out by Morling, J., in Thornburg v. James E. Bennett $\&$ " Co. ${ }^{18}$ "Four things are under this statute essential to the validity of such service. The defendant inust: (1) Have an office or agency in the county. (2) A county other than that in which he resides. (3) The action nnust grow out of or be connected with the business of that office or agency. (4) The agent or clerk upon whom service is inade must be employed in such office or agency."

The need for and reasonableness of legislation of this type under modern conditions is clear. In the absence of such legislation a plaintiff ordinarily would be forced to begin his suit in the state of defendant's residence unless the defendant comes into the state where plaintiff resides. To force plaintiff to sue in the state of defendant's residence seems a hardship as to causes of action arising out of business transacted within the state of plaintiff's resiclence. The hardship of coinpelling defendant to leave his domicillary state and litigate in plaintiff's state is less because defendant has chosen to enter plaintiff's home state and solicit and engage in business there. Plaintiff has the better side of the hardship argument.

The reasonableness of the inethod employed of notifying defendant is unquestionable. He selects as his agent for business purposes the person upon whoin the summons is served. Such a person is a suitable one to receive the summons and notify his principal. The decision is based upon correct legal principles and reaches a desirable result.

How far state statutes should go, and can constitutionally go, in providing for personal service upon non-residents is an interesting question not free froun difficulties. The problem likely will be solved by numerous decisions when different fact situations are presented. One observation will be made. No sound reason is seen why non-residents may not be and should not be subject to suit, the object of which is a personal judgment, for causes of action arising out of any business transacted within the state. Whether the business is one subject to

18 (1928) 205 Iowa 1187, 221 N. W. 840. (Here the return was held insuffcient.)

Morling, J., dissented in Davidson v. Doherty \& Co., supra note 4. He stated that the Iowa statute did not provide that the agent served be one employed "in the particular transaction"; that the agent is not required to transmit the notice of suit to his principal. Certainly the latter criticism is not substantial. The principal appoints his agent and he must bear the risk of his agent's omission to do his duty. Washington ex rel. Bond, Goodwin \&: Tucker v. Superior Court (1933) 289 U. S. 361 . In statutes providing for substituted service the person served inust be one reasonably expected to notify the party sued. The statute reads service may be made on "any agent or clerk employed in such office or agency." The limitations made seem to exclude employees unlikely to notify the employer. 
"special regulation," as Mr. Justice McReynolds observed of the business of dealing in securities, does not seem to be a controlling factor. In the not distant future the courts probably will be confronted with the question of the validity of statutes providing for methods of service upon non-residents for causes of action arising out of business that is not specially regulated, and also out of wrongful conduct other than negligent operation of automobiles. The tendency in recent years is to enlarge the jurisdiction of the state over non-residents committing wrongs while temporarily there.

J. P. McBaine.

ScHOOL OF JURISPRUdENCE,

University of Calmorinta. 